\title{
POTATOES AND THE HISPANIC ENLIGHTENMENT
}

\begin{abstract}
A
mong the new publications tempting Spanish readers in 1785 , alongside a comedy about jealous women, a how-to manual on forensic surgery, and a 600-page translation of the rulings of the Council of Trent, was a modest pamphlet about potatoes. Its author was an expatriate Irishman, Henry (or Enrique) Doyle. Doyle had for some decades resided in Spain, pursuing an undistinguished career in textile manufacturing. He had also drafted several essays on religious themes, with no impact whatsoever on the Spanish reading public. His writings on potatoes, however, were a phenomenal success. The 1785 pamphlet was followed in 1797 by a longer treatise issued with royal approbation at the behest of several important ministers, which was into its fourth edition by 1804. Newspapers and journals hailed Doyle as a patriotic and enlightened contributor to public happiness and seconded his ambition of extending potato cultivation across the length and breadth of Spain. ${ }^{1}$
\end{abstract}

According to Doyle, the potato was a virtual wonder-food. Drawing on his familiarity with Ireland, he informed Iberian readers that the tuber was "healthy and nourishing," and in northern countries adorned the tables of the rich while also sustaining the poor, "who eat scarcely any other food, and with this diet stay healthy and robust.” It was immensely versatile, as it could be consumed in so many different ways:

\footnotetext{
It is a pleasure to thank the generous colleagues whose expertise and keen eyes enriched my own investigations. Sophie Brockmann shared her knowledge of eighteenth-century Guatemala. Kathryn Santner told me about, and provided copies of, documents from Arequipa archives, and Dennis Landis helped me with Dávalos's Latin. I am also very grateful to the John Carter Brown Library for fellowship and enormously stimulating environment that together made it possible for me to think about potatoes in Peru. My thanks also extend to the anonymous reviewers for The Americas.

1. Enrique Doyle, Instrucción formada de orden del Consejo por D. Enrique Doyle, para el cultivo y uso de las patatas (Madrid, 1785); Enrique Doyle, Tratado sobre el cultivo, uso y utilidades de las patatas o papas, corregido y considerablemente aumentado (Madrid, 1804); and for a Portuguese translation, Henrique Doyle, Tractado sobre a cultura, uso e utilidade das batatas ou papas (Lisbon, 1800). For the other 1785 publications, see Memorial literario instructive y curioso de la Corte de Madrid, 5:342 (1785), 324-353. On Doyle, see Memorias de la Sociedad Económica 4 (Madrid, 1787), appendix, 51-52; and Eugenio Larruga, Memorias politicas y económicas sobre los frutos, comercio, fábricas y minas de España 17 (Madrid, 1792), 286-292.
} 
. . . boiled, roasted, fried, in salads, in stews or mixed with other vegetables. Peeled and dressed with salt, garlic, oil and water it is a good, very cheap food for the poor. Eaten with butter they are nourishing and enjoyable. Cooked, peeled, and mixed with sugar, lard and eggs they can be used to make tarts, puddings and other delicate pastries; dissolved in broth or milk, it is a healthy and nourishing food for nursing infants and children. ${ }^{2}$

Doyle expatiated on the potato's many merits, which included not only its culinary qualities, but also its potential as an animal feed, the ease of cultivating it, and its medical ability to correct acrid humours.

Doyle's treatise on the propagation, cultivation, and use of potatoes was not an anomaly. His passionate and verbose celebration of the potato-the 1804 edition ran to some 250 pages-was one of hundreds of works dedicated to the tuber that were published across late eighteenth-century Europe. Agronomists, gentlemen farmers, botanists, priests, philosophers, and other patriotic individuals penned treatises, conducted experiments, sponsored agricultural competitions, disseminated seed potatoes, and in general mounted a sustained pan-European effort to encourage the cultivation and consumption of potatoes. Although many other edible plants, from Siberian buckwheat to wild rice, also attracted interest, the volume, geographic spread, and messianic tone of these potato-texts is remarkable. ${ }^{3}$ What explains such pervasive interest in the new-world potato?

This article examines potato promotion in the eighteenth-century Hispanic world. Spain's potato-celebration extended beyond Europe, uniting enlightened communities across its empire. The potato's advocates in Spain and its colonies considered the vegetable from the perspective of new ideas about the relationship between food, healthy populations, benevolent governance, and the wealth and grandeur of nations. On both sides of the Atlantic, for men such as Doyle, potatoes formed part of a larger complex of enlightened improvements that would

2. Henrique Doyle, Tratado sobre el cultivo, uso y utilidades de las patatas ó papas, é instrucción para su mejor propagación \& c (Madrid, 1797), 24-25.

3. For potato promotion, see Redcliffe Salaman, History and Social Influence of the Potato, J. G. Hawkes, ed. (Cambridge: Cambridge University Press, [1949] 2000); Ilmar Talve, "The Potato in Finnish Food Economy," Food in Perspective: Proceedings of the Third International Conference on Ethnological Food Research, Alexander Fenton and Trefor Owen, eds. (Edinburgh: John Donald, 1981); Eszter Kisbán, "The Beginnings of Potato Cultivation in Transylvania and Hungary: Government Policy and Spontaneous Process," in The Origins and Development of Food Policies in Europe, John Burnett and Derek Oddy, eds. (London: Leicester University Press, 1994); David Gentilcore, Italy and the Potato: A History, 1550-2000 (London: Bloomsbury, 2012); Emma Spary, Feeding France: New Sciences of Food, 1760 1815 (Cambridge: Cambridge University Press, 2014); and Marika Galli, La conquête alimentaire du Nouveau Monde. Pratiques et représentations franco-italiennes des nouveaux produits du XVIe au XVIIIe siècle (Paris: LHarmattan, 2016). In 1811 a German doctor counted some 200 European texts whose title referred explicitly to potatoes; inclusion of the many works that discussed the tuber would increase the number by a factor of ten. Johann Hermann Becker, Versuch einer allgemeinen und besondern Nahrungsmittelkunde, vol. 1 (Stendal, 1811), 658-680. 
lead, ultimately, to a stronger and more wealthy state. These new ideas about the centrality of nourishing food to the practice of governance crisscrossed the empire, helping to establish the potato as a symbol of enlightenment. Such transatlantic conversations were a characteristic feature of the Enlightenment. Indeed, as scholars increasingly argue, the Enlightenment cannot be understood separately from these global conversations, which in many ways were the Enlightenment.

The potato's eighteenth-century Hispanic career also reveals the varied local articulations of enlightened ideas. Although the potato was a popular object of investigation in many parts of Europe and its colonial hinterlands, savants in Spain and the Indies had a unique relationship with the tuber. As they often noted, it was Spaniards who first introduced potatoes to Europe, and who therefore deserved credit for the increase in human well-being that they insisted it would enable. At the same time, the potato in its Spanish American homeland was a low-status food associated with the indigenous population. There, enlightened celebration of Spain's special relationship with the bounteous potato collided with the hierarchical nature of colonial society. Examination of pan-Hispanic potato promotion schemes illuminates both the global reach of enlightened discourse and its intensely local character. The Enlightenment constituted a process of movement and exchange of objects and knowledge, whose meanings changed as they traveled. This essay's aim is thus to explain why, at a certain moment, individuals across the Hispanic world began to celebrate potatoes, and what this tells us about the Enlightenment. ${ }^{4}$

\section{PRECIOUS ROOT}

The tuber was the beneficiary of an enormous propaganda campaign in late eighteenth-century Spain, aimed at promoting this "precious root." Charles III himself sponsored the publication of Doyle's treatise and in 1784 advised patriotically minded Spaniards to encourage greater use of potatoes. Landlords in various parts of the peninsula followed suit, urging their tenants to plant the tuber. $^{6}$ Even before the monarch threw his weight behind them, potatoes were

4. What this article does not offer is a history of the potato's actual penetration into local diets in Spain, or its trajectory from the Andean highlands to other parts of the Spanish Indies. That, as they say, is another story. For a brief sketch of this process see Rebecca Earle, "Promoting Potatoes in Eighteenth-Century Europe," Eighteenth-Century Studies 51:2 (2017), 147-162.

5. Dionisio Escudo, Ampudia, February 20, 1798, Semanario de Agricultura y Artes Dirigido a los Párrocos, Madrid [hereafter $S A A]$ 3, April 19, 1798, 253.

6. J. David Palanca Cañon, "Introducción y generalización del cultivo y consumo alimentario y médico de la patata en el País Vasco: 1760 a 1860" (D.Phil. Universidad del País Vasco, 2011), 46. On the royal order, see Extractos de las juntas generales celebradas por la Real Sociedad Bascongada de los Amigos del País en la cindad de Vitoria por julio de 1786 (Vitoria, 1786), 28; Doyle, Instrucción; and Doyle, Tratado, 9-11. 
embraced by the "economic" societies established in increasing numbers in the second half of the eighteenth century in many Spanish cities. These organizations brought together avowedly enlightened members of the bourgeoisie and aristocracy for the purpose of advancing useful knowledge within an explicitly patriotic framework. Agricultural improvements loomed large in their concerns. Alongside their investigations of new fodder crops and superior manures they consistently championed the potato as an excellent source of food for both people and animals. ${ }^{7}$

Economic societies in Madrid, Aragón, and elsewhere employed their standard repertoire of techniques-sponsored competitions, published essays, practical experiments - to encourage potato cultivation and consumption. The Real Sociedad Económica Matritense de Amigos del País, for instance, regularly offered premiums for the farmer who harvested the largest potato crop. The Real Sociedad Económica de Valencia did likewise. The Basque Society also offered prizes and conducted experiments in potato cultivation and the manufacture of potato bread, an object of particular fascination across Europe. They, like their counterparts in other parts of the peninsula, translated an array of agricultural treatises on the potato, because, as they explained in a 1786 report, they had long considered the potato "one of the most important crops that could be introduced to the benefit of the country." They also arranged for Doyle's pamphlet to be read in public venues, to disseminate his promotional message. ${ }^{8}$ Botanists experimented with new varieties and new methods of cultivation, and publicized their findings in journals and memoirs. The potato, reported Claudio Boutelou, head gardener at the Real Jardín Botánico de Madrid, "is without doubt the most valuable item we have received from the

7. For economic societies in the Hispanic world and elsewhere, see Robert Jones Shafer, The Economic Societies in the Spanish World (1763-1821) (Syracuse: Syracuse University Press, 1958); Enrique Martínez Ruiz and Magdalena de Pazzis Pi Corrales, eds., Ilustración, ciencia y técnica en el siglo XVIII español (Valencia: Universitat de València, 2008); Gabriel Paquette, Enlightenment, Governance, and Reform in Spain and Its Empire, 1759-1808 (Houndmills, UK: Palgrave Macmillan, 2008); Koen Stapelbroek and Jani Marjanen, eds., The Rise of Economic Societies in the Eighteenth Century (Basingstoke, UK: Palgrave Macmillan, 2012); and Jesús Astigarraga, "Economic Societies and the Politicisation of the Spanish Enlightenment," The Spanish Enlightenment Revisited, Jesús Astigarraga, ed. (Oxford: Voltaire Foundation, 2015).

8. On the Basque Society see Extractos de las juntas generales celebradas por la Real Sociedad Bascongada ... julio de 1786 (Vitoria, 1786), 28 (quote); and Luis Riera Climent and Juan Riera Palmero, "Los alimentos americanos en los Extractos de la Bascongada (1768-1793): el maíz y la patata," Llull 30 (2007), 319-332. On the importance of such translations see Javier Usoz, "Political Economy and the Creation of the Public Sphere during the Spanish Enlightenment," The Spanish Enlightenment Revisited, Astigarraga, ed., 117-122. For other examples of pro-potato activity by economic societies, see "Explicación de la voz batata para incluir en un diccionario de la lengua," Memorial Literario, Instructivo y Curioso de la Corte de Madrid 121 (November 1790), 365; Correo Mercantil de España y sus Indias, March 24, 1794, 188, and August 10, 1801, 50; Correio Mercantil e Economico de Portugal, April 24, 1798; SAA, March 13, 1800, vol. 7 (1800), 173; Junta pública de la Real Sociedad Económica de Amigos del País de Valencia (Valencia, 1801); $S A A$, December 9, 1802, vol. 11 (1802), 173; and Juan Piqueras Haba, "La difusión de la patata en España (1750-1850): el papel de las sociedades económicas y del clero rural," Ería: Revista Cuatrimestral de Geografia 27 (1992). 
New World." In his view, potatoes, rather than silver, constituted the Americas' greatest contribution to European well-being and prosperity. ${ }^{9}$

This potato-talk resonated across the pages of Spanish newspapers, including the state-sponsored Semanario de agricultura y artes dirigido a los párrocos, which was founded in 1797 with the express purpose of disseminating useful knowledge on all manner of agricultural enterprises. ${ }^{10}$ Its many articles on potatoes explained new methods of cultivation and storage, described how to convert them into animal food, and detailed the tastiest ways of consuming them. ${ }^{11}$ The Semanario's editors calculated the relative productivity of potatoes and wheat, concluding that wheat was more labor-intensive, used more fertilizer, and produced a vastly lower yield. ${ }^{12}$ It published extracts from English and French works on the potato, as well as, naturally, an enthusiastic review of Doyle's treatise. ${ }^{13}$ Interested subscribers were offered seed potatoes gratis so that they could conduct their own experiments. ${ }^{14}$

The Semanario moreover published letters from readers reporting on their successes in growing potatoes and cajoling others to eat them. ${ }^{15}$ Particularly extensive correspondence came from the parish priest of the town of Linares, in Salamanca. Having read about the benefits of using potatoes in place of wheat flour when making bread, he determined to encourage their use among his parishioners and tenants. ${ }^{16}$ As he insisted, society received far greater benefit from such practical schemes to "improve and increase our supply of food," than from abstract, esoteric knowledge about great men or historical events of past

9. $S A A$, July 4, 11, 1805, vol. 18 (1805); $S A A$, February 20 and March 6, 1806, vol. 19 (1806); Casimiro Gómez de Ortega, Elementos teóricos-prácticos de agricultura . . . traducidos del francés del célebre Mr. Duhamel de Monceau, 2 vols. (Madrid, 1805), 2:137; Estéban Boutalou, "Memoria sobre las patatas," SAA, March 6, 1806, vol. 19 (1806); and Gabriel Alonso de Herrera, Agricultura general de Gabriel Alonso de Herrera, corregida según el texto original de la primera edición publicada en 1513 por el mismo antor y adicionada por la Real Sociedad Económica Matritense (Madrid, 1819), III:248 (quote).

10. Elisabel Larriba, "Un intento de reforma agraria por y para las clases productoras: el Semanario de agricultura y artes dirigido a los párrocos (1797-1808)," Brocar 23 (1999); Elena Serrano, "Making Oeconomic People: The Spanish Magazine of Agriculture and Arts for Parish Rectors (1797-1808)," History and Technology 30:3 (2014).

11. $S A A$, November 21, 1799; January 23, 30, February 27, March 6, 13, 29, April 3, June 19, July 9, 16, 1800, vol. 7 (1800); September 24, 1801; September 24, 1802, November 18, 1802, December 9, 1802; April 18, 1805, June 20, 1805, vol. 17 (1805); April 17, 1806, vol. 19 (1806). For other newspaper reports, see, for instance, Gaceta de Madrid, Madrid, March 17, 1789, 196; Memorial Literatio Instructivo y Curioso de la Corte de Madrid, issue 21 (1790), 365; and Correo Mercantil de España y sus Indias, Madrid, March 24, 1794, 188; August 3, 10, 1801, 490, 508.

12. $S A A$, March 20, 27, 1806, vol. 19 (1806).

13. See, for instance, $S A A$, November 21, 1799, vol. 6 (1799); January 23, 30, February 27, March 6, April 3, June 19, 1800, vol. 7 (1800); and $S A A$, July, 9, 16 1801, vol. 10 (1801).

14. $S A A$, November 18,1802 , vol. 12 (1802).

15. See, for instance, the letters to the Semanario from Juan Antonio Delgado, Alanis, $S A A$, May 17, 1798, vol. 3 (1798); or the reports and letters from Juan Antonio Pasquel y Rubio, Pedro Nevado, Dionisio Escudo, and an anonymous writer in San Lucar de Barrameda published in 1798. SAA, January 25, February 1, April 19, 26, 1798, vol. 3 (1798).

16. Carta del cura de Linares sobre el cultivo y aprovechamiento de las patatas, $S A A$, October $12,1791$. 
eras. ${ }^{17}$ His first missive prompted letters from other subscribers requesting details, which the priest provided in a series of updates. ${ }^{18}$

The potato's many promoters were quite clear about the reasons for their interest: potatoes ensured a healthy population and so were of vital importance to the state. Doyle was explicit about this associations between potatoes, population, and political economy. As he explained in his 1797 treatise:

As a population grows and multiplies, so it becomes necessary not only to improve the soil and increase the area under cultivation, but also to take advantage of other roots, plants and vegetables suited to the quality of the land and suitable for ordinary people to eat to sustain themselves, in order to keep commerce in balance at moderate prices at all times. Writers agree that the potato supplies this necessary help both because it is abundant and cheap, and also because it is healthful. ${ }^{19}$

Spain's well-being, he concluded, depended not only on the government but also on the "zeal and vigilance of good patriots," who should therefore promote potato consumption by the poor. All this, he made clear, would rebound to the benefit of the economy overall. After all, he insisted, "expensive food and cheap labour are incompatible." 20

Doyle's text provides a clear example of the close associations between food, healthy populations, political economy, and the new models of governance that began to emerge in the late eighteenth century. In particular, enlightened discussion of new foods was inseparable from the ongoing debate over the concept of "population." Philosophers, économistes, officials, and other members of the republic of letters engaged in a prolonged examination of the relationship between the number of people inhabiting a territory and its wealth. Adam Smith expressed well the close connection between the two when he asserted that "the most decisive mark of the prosperity of any country is the increase of the number of its inhabitants." 21 As Michel Foucault argued some decades ago, these population debates signaled a new approach to the exercise of power. ${ }^{22}$ These new strategies of power linked the management and regulation of populations to the economic and military strength of the state.

17. Carta del cura de Linares, $S A A$, October $12,1791$.

18. Carta del párroco de Linares, February 5, 1797, $S A A$, March 30, 1797, vol. 1 (1797); Carta del cura de Linares, $S A A$, November 21, 1799, vol. 6 (1799); Carta del cura de Linares, $S A A$, August 13, 1801.

19. Doyle, Tratado, 4-5 (quote), 78-79, 85.

20. Doyle, Tratado, 6.

21. Adam Smith, An Inquiry into the Nature and Causes of the Wealth of Nations, 2 vols. (London, 1776), 1:86.

22. Michel Foucault, Security, Territory, Population: Lectures at the College de France, 1977-1987, Michel Senellart, ed., Graham Burchell, trans. (New York: Palgrave Macmillan, 2009). 
The strength, size, and productivity of the population thus became increasingly central to new models of governance that viewed the inhabitants of a territory as a resource to be analyzed, developed, and put to use. The state needed to understand, and thereby control, the large forces that shaped "the population." In other words, "the population" was far more than a miscellaneous collection of individuals inhabiting a territory. It was an essential resource. Good governance entailed knowing how many people inhabited the national territory, their economic (and non-economic) activities, and, especially, whether they were fit, healthy, and able to work. ${ }^{23}$

A healthy and economically active population required an ample supply of nourishing food. For this reason, a nation's strength was closely correlated with its possessing "the greatest possible quantity of foodstuffs," as the enormously influential economic theorist Jean-François Melon noted in $1736 .{ }^{24}$ A plentiful supply of food not only ensured a healthy and growing population but also lowered the cost of living, and with it the cost of labor. That combination, in turn, would stimulate commerce and industry, another fundamental responsibility of any enlightened monarch. Such concerns were not purely theoretical. Advocates of these new ideas also hoped that by implementing more effective agricultural and commercial structures states could avoid the politically destabilizing effects of food shortages. Famines such as the one that struck Naples in 1764 reverberated across the continent, provoking riots in Madrid, for instance. ${ }^{25}$ Debates about the merits of free trade in grain, the quest for more efficient foods such as the potato, and investigations into innovative agronomic techniques all reflected this new focus on the relationship between governance, food, and population.

The quality of the food supply, for the eighteenth-century science of the state, was thus both a matter of public order and a central component of a larger model of political economy, a model that associated national wealth and greatness with the energy and vigor of the working population. In this way, abundant, healthy food became increasingly central to the exercise of governance. It is this reconceptualization of the relationship between food and the wealth and power

23. On eighteenth-century populationist discourse, see James Riley, Population Thought in the Age of the Demographic Revolution (Durham: Duke University Press, 1985); Sylvana Tomaselli, "Moral Philosophy and Population Questions in Eighteenth-century Europe," Population and Development Review 14 (1988); Andrea Rusnock, Vital Accounts: Quantifying Health and Population in Eighteenth-Century England and France (Cambridge: Cambridge University Press, 2002); Foucault, Security, Territory, Population; Yves Charbit, The Classical Foundations of Population Thought From Plato to Quesnay (London: Springer, 2011); and Alison Bashford and Joyce Chaplin, The New Worlds of Thomas Robert Malthus: Rereading the Principle of Population (Princeton: Princeton University Press, 2016).

24. Jean-François Melon, Essai politique sur le commerce (n.p., 1736), 12.

25. John Post, "Nutritional Status and Mortality in Eighteenth-Century Europe," in Hunger in History: Food Shortage, Poverty and Deprivation, Lucille Newman, ed. (Cambridge: Blackwell, 1995); and José Andrés Gallego, El motin de Esquilache, América y Europa (Madrid: Consejo Superior de Investigaciones Científicas, 2003). 
of nations that explains why countries from Switzerland to Sweden began to encourage the cultivation of potatoes, and why eighteenth-century philosophes and scientists so assiduously investigated the tuber's many qualities.

A substantial body of scholarship has demonstrated that Spanish officials, scientists, and philosophers closely followed and engaged with these pan-European debates about population, political economy, and the role of efficient agricultural production in fomenting commerce and industry. Spanish writers evaluated the merits of new economic ideas such as those of Adam Smith or the physiocrat François Quesnay. They read French treatises on the potential of innovative agronomic practices to transform commercial agriculture, and they composed their own contributions to these international conversations. ${ }^{26}$ Enlightened Spaniards, moreover, shared the widespread conviction that healthy and economically active subjects were essential to the success of the state. "There is not a single politician," asserted one, "who does not accept the clear fact that the greatest possible number of law-abiding and hardworking men constitutes the happiness, strength and wealth of any state." To demonstrate this was easy, he affirmed, since even the dimmest mind could appreciate that agriculture, commerce, and the arts, the bases of all wealth, increased in proportion to the size of the productive population. A vigorous population also allowed a state to resist foreign invasion, he noted, concluding that "I do not believe it is possible to deny this self-evident truth." 27 "A state's true resources lie in the happiness and robustness of the body politic, in an extensive and prosperous agriculture, in manufacturing, [and] in merchants," agreed Francisco Cabarrús, an important trader and the founder of the Banco de San Carlos. ${ }^{28}$

Spanish writers also shared the consensus that any population, however large, was useless if it was not actively engaged in productive labor. In a treatise

26. On Bourbon science and statecraft, see Ernest Lluch and Lluís Argemí i d'Abadal, Agronomía y fisiocracia en España (Valencia: Institución Alfonso el Magnánimo and Instituto Valenciana D’Estudis i Investigació, 1985); Francisco Javier Puerto Sarmiento, La ilusión quebrada: botánica, sanidad y politica cientifica en la España ilustrada (Madrid: Consejo Superior de Investigaciones Científicas, 1988); Manuel Sellés, José Luis Peset, and Antonio Lafuente, eds. Carlos III y la ciencia de la ilustración (Madrid: Alianza, 1988); José Enrique Covarrubias, En busca del hombre útil. Un estudio comparativo del utilitarianismo neomercantilista en México y Europa (Mexico City: Universidad Nacional Autónoma de México, 2005); Santiago Castro-Gómez, La bybris del punto cero: ciencia, raza e ilustración en la Nueva Granada (Bogotá: Editorial Pontíficia Universidad Javeriana, 2005); Paquette, Enlightenment, Governance, and Reform; and Astigarraga, ed., The Spanish Enlightenment Revisited.

27. Joaquín Xavier de Uriz, Causas prácticas de la muerte de los niños expósitos en sus primeros años, 2 vols. (Pamplona, 1801), 1:6-7. Or see Pedro Rodríguez de Campomanes, Discurso sobre el fomento de la industria popular (Madrid, 1774), 136; Bernardo Ward, Proyecto económico, en que se proponen varias providencias, dirigidas á promover los intereses de España (Madrid, 1779), 70; and José del Campillo y Cosío, Nuevo sistema de gobierno económico para la América (Madrid, 1789), 261.

28. "Discurso sobre la libertad de comercio, concedida por S. M. a la América meridional, presentado a la Real Sociedad de Amigos del Pays, por Don Francisco Cabarrús," February 28, 1778, reprinted in Santos Manuel Coronas González, "Espíritu ilustrado y liberación del tráfico comercial con Indias," Anuario de Historia del Derecho Español (1992): 110 
commissioned by Ferdinand VII on how to energize Spain's economy, Bernardo Ward reiterated that "the most fundamental element of any economic system is ensuring that men are usefully employed." The labor potential latent in the population was an essential resource, and good governance consisted precisely in unlocking this potential. Failure to do so was, Ward stressed, "the most culpable and damaging omission the State could suffer." 29 For him, as for so many other writers, managing the population constituted the core of effective governance.

Spanish promotion of the potato referred directly to these close connections between energetic populations and the wealth and power of the state. Throughout his treatise, Doyle stressed that although the potato was eaten with pleasure by the wealthy, its utility lay fundamentally in its potential as a food for working people. He reiterated that it was highly nourishing, and that potato-eaters were "healthy and robust." Like many other writers, he cited the hearty Irish peasant as evidence for the potato's healthful, sustaining qualities. Moreover, it was because these peasants consumed potatoes that Ireland was able to export millions of pounds of wheat, to the benefit of landowners and the treasury. ${ }^{30}$ A working population subsisting on potatoes therefore fuelled agricultural and commercial success, at least from the perspective of the state and large landowners. The priest from Linares made a similar point when he suggested that greater cultivation and consumption of potatoes would halt the ruinous expense occasioned by Spain's reliance on wheat imports, which served, he predicted, to enrich neighboring states that would one day use this wealth to attack Spain. ${ }^{31}$ The connections between cheap food and a strong state were also demonstrated by the potato's often praised potential as a food for soldiers. Doyle recommended its use in the munition bread commonly served to recruits, and later editions of his treatise pointedly observed the potato's popularity among regimental soldiers in Madrid. ${ }^{32}$

Further adding to its appeal was the potato's ability to promote lactation in nursing mothers, and to provide a suitable substitute for breast-milk, both qualities that Doyle addressed in his treatise. ${ }^{33}$ Infant feeding and its links to

29. Ward, Proyecto económico, 196.

30. Doyle, Tratado, 24-25, 33, 81. For examples of the Irish cited as evidence of the potato's nutritious qualities, see Samuel Engel, Traité de la nature, de la culture et de 'utilité des pommes de terre (Lausanne, 1771), 59; Smith, An Inquiry into the Nature and Causes of the Wealth of Nations, 1:201-202; Parmentier, Les pommes de terre, considérées relativement à la santé é à l'économie, 195; Parmentier, Traité sur la culture et les usages des pommes de terre, de la patate, et du topinambour, 17-18; and David Lloyd, "The Political Economy of the Potato," Nineteenth-Century Contexts 29:2-3 (2007).

31. Carta del cura de Linares, November 21, 1799.

32. Doyle, Instrucción, 26-27; Henrique Doyle, Tratado sobre el cultivo, uso y . . aumentado, 7.

33. Doyle, Tratado, $8,24,31$. 
infant mortality were topics of keen interest in many parts of Europe, precisely because a strong and productive population depended on its ability to reproduce itself. Spanish books on the topic proclaimed this association clearly in their very titles: Concrete Causes of Mortality in Foundlings during their Early Years: Remedies for this Serious Evil, and Method for Making them into Useful and Christian Citizens to the Notable Increase to Spain's Population, Strength and Wealth reads the title of one such work, from 1801. Its author, a priest and trustee at Pamplona's general hospital, stated explicitly that recovering these doomed babies for the state would increase the population of soldiers and workers: "How many individuals_which we now lack-would we have for public works! How many laborers! How many honest grenadiers!" Not surprisingly, he endorsed potatoes as a highly suitable food for orphans. ${ }^{34}$

The active promotion of the potato in late eighteenth-century Spain demonstrates well how the health of individual members of the population became linked to the overall health and stability of the state, and its economy. Late eighteenth-century interest in the potato reflects these new models of statecraft, and the increasing focus on building the energetic populations that would allow the state to reap "the benefits of citizens being usefully occupied," as Charles III put it in 1784. ${ }^{35}$ By promoting potatoes these enlightened bureaucrats, savants and priests both advanced the interests of the Spanish nation, and also demonstrated to other members of the republic of letters their patriotic commitment to public happiness and the common good.

\section{Colonial Potatoes}

To what extent did this association between food, population, and the wealth and happiness of nations extend to Spain's colonial possessions? Colonies played a key role in the new models of statecraft that were under construction in Bourbon Spain. Motivated by enlightened debates over the true sources of national wealth and grandeur, statesmen sought to reform Spain's relationship with its New World possessions to better conform to these new ideas. Converting the Indies

34. Jaime Bonells, Perjuicios que acarrean al género humano y al estado las madres que rehusan criar a sus hijos (Madrid, 1786); Uriz, Causas prácticas de la muerte de los niños, 1:85 (quote), 2:127-130, 157; and Antonio Arteta, Disertación sobre la muchedumbre de niños que mueren en la infancia, y modo de remediarla, y de procurar en sus cuerpos la conformidad de sus miembros, robustez, agilidad y fuerzas competentes, 2 vols. (Zaragoza, 1801-2), 1:16. On the death of foundlings as "a political loss for the state," see Marie France Morel, "Théories et pratiques de l'allaitement en France au XVIIIe siècle," Annales de Démographie Historique 1976:1 (1976); Joan Sherwood, Poverty in Eighteenth-Century Spain: The Women and Children of the Inclusa (Toronto: University of Toronto Press, 1988); Donna Andrews, Philanthropy and Police: London Charity in the Eighteenth Century (Princeton: Princeton University Press, 1989); and Isabel dos Guimarães Sá, "Circulation of Children in Eighteenth-Century Portugal," Abandoned Children, Catherine Panter-Brick and Malcolm Smith, eds. (Cambridge: Cambridge University Press, 2000), 29 (quote).

35. Gaceta de Madrid, October 1, 1784, 820. 
into a productive source of revenue was a central aim of Bourbon reformers. The loose, inefficient structure of Spain's empire irritated these men, who complained that Britain and the Netherlands were far more effective in utilizing the advantages offered by colonies. Their campaign to modernize agricultural and commercial practices thus embraced both Spain and its American empire. ${ }^{36}$

At the same time, the precise value of colonial spaces within the wealthpopulation calculus remained unclear. Did an increase in the colonial population translate into an increase in the state's "happiness, strength and wealth" in the same way as would such an increase in Spain itself? ${ }^{37}$ Enlightened statesmen were uncertain. On one hand, under-population in the Indies was regularly identified as an obstacle to economic growth by both peninsular and colonial writers. Animated by such concerns, a newspaper in New Granada announced a prize of 50 pesos for the best essay on how to solve the problem of under-population. As the advertisement for the competition stated, "Without an increase in the population the kingdom will never experience true happiness."38 Reformers in both Spain and the Americas displayed a particular interest in the size, health, and vitality of the creole population. Projects in sanitation or quarantine systems, criticism of ill-chosen wet nurses, and other endeavours consistently sought to build up the fragile bodies of creoles. $^{39}$

Overall, however, advocates of reform on both sides of the Atlantic were most exercised by the "apathy" that supposedly engulfed much of the American population. This, rather than an absolute shortage of people, was identified as the real obstacle to growth. After all, as the Bourbon official Bernardo Ward noted, "When one says that a sovereign's wealth consists in the number of his vassals, one means the number of useful vassals, since a million idle vagabonds and professional beggars, far from being useful, are an impediment to the state, which would be much better off, and wealthier, without them." ${ }^{30}$ The problem of the Indies, most critics agreed, was not under-population but

36. Antonio Lafuente, "Enlightenment in an Imperial Context: Local Science in the Late Eighteenth-century Hispanic World," Osiris 15 (2000); José M. Portillo Valdés, Crísis atlántica: autonomía e independencia en la crísis de la monarquía hispána (Madrid: Marcial Pons, 2006); and Fidel José Tavárez Simó, "La invención de un imperio comercial hispano, 1740-1765," Magallánica, Revista de Historia Moderna 3 (2015).

37. Uriz, Causas prácticas de la muerte de los niños expósitos, 1:6-7.

38. Papel Periódico de la Ciudad de Santafé de Bogotá, May 6, 1791, in Papel Periódico de la Ciudad de Santafé de Bogotá, 1791-1797, 7 vols. (Bogotá: Banco de la República, 1978), 1:102.

39. See for instance Andrew Knaut, "Yellow Fever and the Late Colonial Public Health Response in the Port of Veracruz," Hispanic American Historical Review 77:4 (1997); Castro-Gómez, La bybris del punto cero; and Mariselle Meléndez, Deviant and Useful Citizens. The Cultural Production of the Female Body in Eighteenth-Century Peru (Nashville: Vanderbilt University Press, 2011).

40. "Discurso sobre la libertad de comercio"; Ward, Proyecto económico 58 (quote); and Campillo y Cosío, Nuevo sistema de gobierno económico, 261. 
underemployment. The winning essay to the New Granadan competition explained this clearly. Citing writers such as Ward, it stated that "a kingdom cannot be said to be well populated, even if it is bursting with inhabitants, if the latter are not hardworking and engaged in useful labour." ${ }^{\text {"1 }}$ The Americas were apparently full of perfectly capable people who were not doing anything productive, and an increase in the American population was thus not a central aim of enlightened projects of reform. As a result, the close associations European philosophers perceived between healthy populations, food supply, and the wealth of nations loosened when placed in a colonial context. If anything, food was said to be excessively abundant, making it all too easy to live a life of idleness and inactivity. ${ }^{42}$ Nourishing foods retained their powerful symbolic charge as an emblem of good governance, but their practical ability to increase the working population was far less relevant there.

Colonial discussion of the potato demonstrates well this cleavage between the practical and the discursive. The vigorous European pro-potato propaganda resonated strongly with the concerns of enlightened savants in Spanish America eager to demonstrate their commitment to the pursuit of useful knowledge and the public good. Creole elites across the Indies lauded the potato as a distinctly American contribution to human happiness, and emphasized Spain's (and their own) commitment to advancing botanical science through the investigation of valuable New-World foodstuffs. Their discussion of the potato helped articulate a colonial vision of paternalist improvement and benevolence. At the same time, colonial potato-boosters engaged in few practical schemes designed to increase potato consumption.

A clear example is provided by the Real Sociedad Económica de Amantes de la Patria de Guatemala, founded in 1796 by members of the landed and merchant elite. ${ }^{43}$ Like its analogues in Spain, the Guatemalan Society was committed to the dissemination of useful knowledge, with improved agricultural techniques featuring largely in its concerns. As the society stressed, its mission was "the

41. Diego Martín Tanco, "Discurso sobre la población," June 1, 1792, Papel Periódico de la Ciudad de Santafé de Bogotá, 2:132; Juan Pedro Viqueira Albán, Propriety and Permissiveness in Bourbon Mexico, Sonya Lipsett-Rivera and Sergio Rivera Ayala, trans. (Wilmington: SR Books, 1999); Castro-Gómez, La hybris del punto cero.

42. Joseph Ignacio de Lequanda, "Discurso sobre el destino que debe darse a la gente vaga que tiene Lima," Mercurio Peruano de Historia, Literatura, y Noticias Públicas, Lima [henceforth MP], February 16, 1794, 111.

43. On the Guatemala Society and its publications, see Elisa Luque Alcaide, La Sociedad Económica de Amigos del País de Guatemala (Seville: Escuela de Estudios Hispano-Americanos, 1962); Sophie Brockmann, "Surveying Nature: The Creation and Communication of Natural-Historical Knowledge in Enlightenment Central America" (D.Phil., Cambridge, 2013); and Jordana Dym, "Conceiving Central America: A Bourbon Public in the Gazeta de Guatemala (1797-1807)," in Enlightened Reform in Southern Europe and Its Atlantic Colonies, c. 1750-1830, Gabriel Paquette, ed. (London: Routledge, 2016). See also Gabriel Paquette, "State-Civil Society Cooperation and Conflict in the Spanish Empire: The Intellectual and Political Activities of the Ultramarine Consulados and Economic Societies, c. 17801810," Journal of Latin American Studies 39 (2007). 
perfecting of agriculture and the mechanical arts." Most of its attention to agriculture was focused on commercial crops; the "decay" of cacao cultivation was a topic of persistent concern, as were efforts to develop the linen industry. ${ }^{44}$ The society also experimented with new fodder crops such as Guinea grass, for which it sought out seeds and published guides to cultivation. ${ }^{45}$ Another concern was the kingdom's food supply. The society's newspaper, the Gazeta de Guatemala, echoed the views of Spanish economic theorists that it was impossible for arts and industry to flourish when food was expensive or scarce. The Gazeta monitored the availability and cost of basic foodstuffs such as maize, and reported on fluctuations in both. ${ }^{46}$

Members of the Guatemalan Society were perfectly familiar with the potato's lofty reputation in Spain. Through its subscription to Spain's principal agricultural journal, the Semanario de agricultura y artes, members were able to follow that paper's regular reports on the potato's merits and its promotion by states and economic societies across Europe. ${ }^{47}$ As a result, the Society was well placed to replicate the enlightened potato talk that featured so prominently in Spanish publications. The Gazeta and the society's annual reports reprinted extracts from the essays of the celebrated Count Rumford, famous for his low-cost potato soup. Likewise, the Gazeta reproduced Spanish recipes for economical potato bread, such as the one popularized by the letter-writing priest from Linares, who believed it would reduce his parishioners' reliance on expensive wheat. ${ }^{48}$ In Guatemala, however, and in contrast to the situation in Spain, potatoes were in short supply. Potato bread and Rumford soup scarcely provided useful alternatives to local staples, which were based on maize. Nor did the society make any other effort to increase potato consumption among Guatemalans, a major aim of analogous European organizations. They sponsored no competitions for the largest potato harvest, disseminated no seed

44. Periódico de la Sociedad Económica de Guatemala, Nueva Guatemala, May 1, 1815 (quote); Junta pública de la Real Sociedad Económica de Amantes de la Patria de Guatemala (Nueva Guatemala, 1796), 7-10; Noticia de la pública distribución de los premios aplicados a las mejores hilanderas al torno (Nueva Guatemala, 1796); Segunda junta pública de la Real Sociedad Económica de Amantes de la Patria de Guatemala (Nueva Guatemala, 1797); Tercera junta pública de la Real Sociedad Económica de Amantes de la Patria de Guatemala (Nueva Guatemala, 1798); Quarta junta pública de la Real Sociedad Económica de Amantes de la Patria de Guatemala (Nueva Guatemala, 1798); Gazeta de Guatemala, Nueva Guatemala [hereafter GG], April 2, 1798, 56; April 21, 1798, 88; Antonio García Redondo, Memoria sobre el fomento de las cosechas de cacaos y de otros ramos de agricultura (Nueva Guatemala, 1799); and Octava junta pública de la Real Sociedad Económica de Amantes de la Patria de Guatemala (Nueva Guatemala, 1811).

45. GG, supplement no. 57 (1798); February 28, 1803,39-40, and March 7, 1803, 45; and Periódico de la Sociedad Económica de Guatemala, Nueva Guatemala, November 15, 1815, 219, and February 1, 1816, 298-299.

46. Nicolás de Arriquibar, Recreación política: reflexiones sobre el amigo de los hombres en su tratado de población (Vitoria, 1779), 150-161; and GG, February 28, 1803, 33; July 18, 1803, 286-287.

47. The Guatemala Society subscribed in 1798, a year after its launch: Quarta junta pública.

48. GG, June 14, 1802, 145, and February 7, 1803, 10; and Octava junta pública, 23. On Rumford soup, see Benjamin Thompson "Of Food, and Particularly of Feeding the Poor," Essays, Political, Economical and Philosophical, 3 vols. (London, 1797-1803), 1:189-299; and Fritz Redlich, "Science and Charity: Count Rumford and his Followers," International Review of Social History 16:2 (1971). 
potatoes, and published no pamphlets explaining cultivation techniques "in simple language," although they adopted all these methods in their efforts to promote Guinea grass and other commercial crops. In lauding potatoes, the society's did not aim, evidently, to address practical concerns about food supply.

Rather, potato-talk was Enlightenment-talk. The Guatemalan Society's enthusiasm for the potato reflected its commitment to an Atlantic conversation about enlightenment-what the historian Jordana Dym calls a "shared Enlightenment agenda." As scholars have long argued, such conversations to a significant degree were the Enlightenment. When colonists in Guatemala (or philosophers in Prussia) referred to enlightenment they had in mind not only practical schemes for the betterment of mankind, but also a desire to keep up to date with new developments, and the conviction that the exchange of ideas would in itself lead to greater harmony and human happiness. Ilustración was a discursive practice and a state of mind. ${ }^{49}$

Discussion of potatoes thus demonstrated the society's fluency in the language of improvement, public happiness, and good governance. This, of course, was one of the functions that colonial botany served in Spain itself. As the historian Daniela Bleichmar has noted of the novel plants grown in Madrid's botanical garden, "Their value lay in their foreignness, and the botanical garden used them to strengthen its prestige," quite independently of the success of any particular scheme of agricultural promotion and acclimatization. In Spain and Guatemala, as elsewhere, botanical knowledge was a form of cultural capital. ${ }^{50}$ Recipes for potato bread therefore appeared in the Gazeta de Guatemala alongside up-to-date references to European philosophers, debates over the

49. Jürgen Habermas, The Structural Transformation of the Public Sphere: An Inquiry into a Category of Bourgeois Society, Thomas Burger, trans. (Cambridge: MIT Press, 1991); Astigarraga, ed., The Spanish Enlightenment Revisited; and Dym, "Conceiving Central America," 117 (quote).

50. Daniela Bleichmar, Visible Empire: Botanical Expeditions and Visual Culture in the Hispanic Enlightenment (Chicago: University of Chicago Press, 2012), 140. On colonial botany, see J. H. Galloway, "Agricultural Reform and the Enlightenment in Late Colonial Brazil', Agricultural History 53:4 (1979); David Mackay, In the Wake of Cook: Exploration, Science and Empire, 1780-1801 (New York: St. Martin's Press, 1985); Michael Osborne, Nature, the Exotic, and the Science of French Colonialism (Bloomington: Indiana University Press, 1994); David Philip Miller and Peter Hanns Reill, eds., Visions of Empire: Voyages, Botany, and Representations of Nature (Cambridge: Cambridge University Press, 1996); James McClellan III and François Regourd, "The Colonial Machine: French Science and Colonization in the Ancien Regime," Osiris 15 (2000); Richard Drayton, Nature's Government. Science, Imperial Britain, and the "Improvement" of the World (New Haven: Yale University Press, 2000); Emma Spary, Utopia's Garden: French Natural History from Old Regime to Revolution (Chicago: University of Chicago Press, 2000); Julien Touchet, Botanique ê colonisation en Guyane Française (1720-1848) (Cahors: Ibis Rouge, 2004); Castro-Gómez, La hybris del punto cero; Londa Schiebinger and Claudia Swan, eds. Colonial Botany: Science, Commerce and Politics in the Early Modern World (Philadelphia: University of Pennsylvania Press, 2005); Paula de Vos, "Natural History and the Pursuit of Empire in Eighteenth-Century Spain,” Eighteenth-Century Studies 40:2 (2007); Londa Schiebinger, Plants and Empire: Colonial Bio-prospecting in the Atlantic World (Cambridge: Harvard University Press, 2009); James McClellan III, Colonialism and Science: Saint Domingue in the Old Regime (Chicago: University of Chicago Press, 2010); and Fredrik Jonsson, Enlightenment's Frontier: The Scottish Highlands and the Origins of Environmentalism (New Haven: Yale University Press, 2013). 
merits of breastfeeding, public health campaigns, and articles attesting to the need to modernize agricultural practices. In this way the society's members were able to inscribe themselves into the republic of letters, regardless of the practical impact of their endorsement of the potato.

The gulf between the potato's importance as an emblem of Enlightenment and its relevance as a foodstuff is particularly clear in the case of Peru, where Spaniards first encountered the potato in the sixteenth century. The Peruvian analogue of the Guatemalan Society was the Sociedad Académica de Amantes de Lima, founded in 1790 by a group of largely creole intellectuals based in the viceregal capital. Its members enthusiastically embraced the rhetoric of utility, reason, and enlightenment. Their journal, the Mercurio Peruano, published from 1791, returned repeatedly to the need to foment agriculture, commerce, and industry, and displayed a keen awareness of the importance of natural history, in particular, to wealth and improvement. As the botanizing bishop of Trujillo observed in a letter reprinted in the Mercurio, knowledge of natural history and geography was vitally important to governance. ${ }^{51}$ The journal likewise detailed the useful and unusual plants cultivated in Lima's botanical garden and described Spain's numerous state-funded botanical expeditions around the world. "States have always viewed the acquisition of new plants as matters of public interest . . . Our capital has not been dozing in this regard: we do not lack inquisitive patriots who for the last thirty years have laboured to adorn our fertile country with whatever they can acquire from the vegetable kingdom,” the journal boasted in $1794 .^{52}$

The Peruvian Society lauded Spain's role in introducing the potato to Europe, which in its view helped disprove hostile assertions that Spain's colonization of the Americas had contributed nothing to the advancement of humanity. Philosophes such as Voltaire or the Abbé Raynal might claim that the world had derived no benefit from these colonial endeavours, but for Peru's enlightened savants the potato offered an effective rebuttal. ${ }^{53}$ Viewed from this perspective, the potato was evidence of the contributions of both Peru and Spain to knowledge and participation in the community of enlightened states. Spanish

51. Baltasar Jaime Martínez Compañón to Charles IV, MP 11 (1794), 3; Meléndez, Deviant and Useful Citizens, 45-46; and Emily Berquist Soule, The Bishop's Utopia: Envisioning Improvement in Colonial Peru (Philadelphia: University of Pennsylvania Press, 2014). On the Mercurio, see Rosa Zeta Quinde, El pensamiento ilustrado en el Mercurio Peruano, 1791-1794 (Piura: Universidad de Piura, 2000).

52. Francisco González Laguna, "Memoria de las plants extrañas que se cultivan en Lima introducidas en los últimos 30 años hasta el de 1794,” MP 11 (1794), June 10 and 13, 1794, 163 (quote), 165-177.

53. Voltaire, Essai sur les moeurs et l'esprit des nations (1752), Oeuvres completes de Voltaire (Basel, 1785), 19:343; Antonello Gerbi, The Dispute of the New World. The History of a Polemic, 1750-1900 (Pittsburgh: University of Pittsburgh Press, [1955] 1973). 
writers made similar claims. The potato alone, insisted the letter-writing priest from Linares in one of his many communications to the Semanario, vindicated all the labors of Spain's under-appreciated conquistadors. ${ }^{54}$ The same point was made by other contributors to the journal, who agreed that through the potato Spaniards had provided nourishing sustenance for an ungrateful world. ${ }^{55}$ These writers were particularly annoyed by the widely held (and enduring) view that potatoes had in fact been brought to Europe by Walter Raleigh. They patiently explained that it was Spaniards to whom the universe was indebted. ${ }^{56}$ (French philosophers were unconvinced by such defences of Spanish colonialism. "How dare you try to balance the scales with the cochineal insect [and] the potato?" complained the Scientific Academy of Lyon. ${ }^{57}$ )

At the same time, enlightened Peruvians could not have been less enthusiastic about potatoes when it came to eating them. Europeans first encountered potatoes in the Andes, where they formed an important part of the local diet, alongside maize, quinoa, and a range of vegetables. Settlers quickly associated this unfamiliar tuber with the indigenous population. As one of the earliest European descriptions stated, the potato was "a certain food eaten by Indians." ${ }^{58}$ Chroniclers and travellers consistently stressed the centrality of potatoes to the indigenous diet, and described in detail both the ways in which potatoes were consumed and the novel methods employed in making chuño, the long-lasting freeze-dried potatoes that formed a staple for the region. These foods, colonial writers agreed, were "the bread of the Indians." 59

54. SAA, March 30, 1797.

55. "Continuación de los elementos de historia 'natural'," $S A A$, March 28, 1805, 17 (1805).

56. See, for instance, Engel, Traité de la nature, de la culture et de l'utilité des pommes de terre, 11; David Henry, The Complete English Farmer (London, 1771), 283; Antoine Augustin Parmentier, Traité sur la culture et les usages des pommes de terre, de la patate, et du topinambour, 3; and Joseph Banks, "An Attempt to Ascertain the Time when the Potatoe (Solanum tuberosum) was first introduced into the United Kingdom," Transactions of the Horticultural Society of London 1 (London, 1812).

57. 'Coup d'oeil sur les quatre concours qui ont eu lieu en l'Académie des Sciences, Belles-Lettres ể Arts de Lyon sur la découverte de l'Amérique (Lyon, 1791), 14; Jeremy Caradonna, The Enlightenment in Practice: Academic Prize Contests and Intellectual Culture in France (Ithaca, NY: Cornell University Press, 2012), 158-159.

58. Domingo de Santo Thomas, Grammatica, o Arte, que ha compuesto de la lengua general de los indios de los reynos del Perú (Valladolid, 1560), 159v.

59. Pascual de Andagoya, "Relación que da el Adelantado de Andagoya de las tierras y provincias que abajo se hará mención," Relación y documentos, Adrian Blázquez, ed. (Madrid: Historia 16, [1545] 1986), 138-139; Pedro de Cieza de León, Parte primera de la chrónica del Perú (Seville, 1553), Book 1, chapt. 40; "Descripción y relación de la Provincia de los Yauyos," 1586; "Descripción de la tierra del repartimiento de San Francisco de Atunrucana y Laramanti," 1586; and "Relación de la Provincia de los Collaguas," all in Relaciones geográficas de las Indias: Perú, 3 vols., Marcos Jiménez de la Espada, ed. (Madrid, 1965), 1:156, 234, 586; José de Acosta, Natural and Moral History of the Indies, Frances López-Morillas, trans. (Durham: Duke University Press, [1590] 2002), 148, 201-202; Louis Feuillée, Histoire des plantes médicinales que sont le plus en usage aux Royaummes de l'Amerique Meridionale, du Perou \& du Chily, composée sur les lieux par order du Roy, dans les années 1709, 1710 \& 1711 (Paris, 1714-25), 2:62-63; Amadé Frezier, A Voyage to the South-Seas, and Along the Coasts of Chili and Peru in the Years 1712, 1713 and 1714 (London, 1717), 67; Juan Ignacio Molina, Compendio de la historia civil del veyno de Chile (Madrid, 1795), 120-121, 213; and Plutarco Naranjo Vargas, "La comida andina antes del encuentro," in Conquista y comida: consecuencias del encuentro de dos mundos, Janet Long, ed. (Mexico City: Universidad Nacional Autónoma de México, 1997). 
Potatoes were moreover important within Andean religion, a fact of which colonial writers were well aware. The Jesuit naturalist and theologian José de Acosta, for instance, noted in his 1590 Natural and Moral History that Amerindians venerated certain oddly shaped potatoes, "which they call llallahuas and kiss and worship." In precolonial times potatoes were often presented as offerings to deities, constituting both a gift and a meal. Catholic investigations into the persistence of "idolatry" revealed that potatoes continued to feature in clandestine religious ceremonies well after the establishment of the colonial state. Such documents record offerings of potatoes, alongside coca leaves, llama fat, guinea pigs, and other objects also strongly associated with the indigenous world. These associations endured in both community memories and ongoing agricultural practices. The Andean chronicler Felipe Guaman Poma de Ayala described clearly the interconnections between the agricultural cycle, and in particular the planting and harvesting of potatoes and maize, and the religious rituals that once underpinned the Inca state. Other accounts recorded the veneration of the Potato Mother, daughter of the earth goddess Pachamama, and the adventures of Huatya Curi, the mythic "Baked Potato Gleaner." Multiple sources also described the cyclical connections that linked human bodies to plants and the universe. From both a culinary and a cosmological perspective, the potato belonged to the Amerindian world, a position that it has to some degree maintained. ${ }^{60}$

In the viceroyalty's hierarchical culture, the association with indigenous people was scarcely an endorsement of the potato's relevance as a food for Europeans or creoles. Indeed, there is some evidence that even before the arrival of Europeans potatoes did not enjoy a particularly high status as a foodstuff. ${ }^{61}$ To be sure, the realities of life in the colonial Andes meant that in practice potatoes penetrated deeply into the foodways of the settler class. The pampered nuns at the convents of Santa Teresa and Santa Catalina in Arequipa regularly consumed potatoes, as their account books reveal. Even chuño, sprinkled with sugar, sometimes found its way onto such tables. The colonial diet was

60. Cristóbal de Molina, Relación de las fábulasy ritos de los incas, c. 1573, Paloma Jiménez del Campo, ed. (Madrid: Vervuert, 2010), 62-63; Acosta, Natural and Moral History, 262 (quote); Gregorio García, Origen de los indios del Nuevo Mundo, Franklin Pease, ed. (Mexico City: Fondo de Cultura Económica, [1607] 1981); Felipe Guaman Poma de Ayala, El primer nueva corónica y buen gobierno, 1615-16, esp. chapters 11, 12, 37, Guaman Poma website, www.kb.dk/permalink/ 2006/poma/info/en/frontpage.htm, accessed July 2, 2018; Karen Spalding, Huarochiri: An Andean Society Under Inca and Spanish Rule (Stanford: Stanford University Press, 1984), 63, 262; Irene Silverblatt, Moon, Sun, and Witches: Gender Ideologies and Class in Inca and Colonial Peru (Princeton: Princeton University Press, 1987); Mary Weismantel, Food, Gender, and Poverty in the Ecuadorian Andes (Philadelphia: University of Pennsylvania Press, 1988); Frank Salomon and George Urioste, The Huarochiri Manuscript: A Testament of Ancient and Colonial Andean Religion (Austin: University of Texas Press, 1991), 54-73, 120, 131; and Regina Harrison, Signs, Songs, and Memory in the Andes (Austin: University of Texas Press, 1989).

61. John Murra, "Rite and Crop in the Inca State," Culture in History. Essays in Honor of Paul Radin, Stanley Diamond, ed. (New York: Octagon, 1960). 
inevitably a compromise between practicality and aspiration, as scholars such as Jeffrey Pilcher have shown. ${ }^{62}$ Nonetheless, for the Mercurio's writers and readers, potatoes were strongly connected to the indigenous world, and therefore to poverty and backwardness. The Mercurio's discussion of the tuber largely reproduced this set of associations. "Paltry" and "miserable" were the words most closely linked to potatoes in its pages. ${ }^{63}$

Worse, some Peruvian writers suspected that potatoes were actually unhealthy. In the thesis that earned him a medical degree from the University of Montpellier, the limeño José Manuel Dávalos attributed the ailments typically afflicting the city's residents to their overuse of local foodstuffs, most notably heavily seasoned pork, manioc, and potatoes. Citing Linnaeus, Dávalos noted that the potato "is a true species of Solanum, and hence it is easy to judge it to be suspect. If used frequently it produces a harmful effect, even in small quantities." ${ }^{64}$ The Mercurio likewise published warnings about the lethal effects of excessive potato consumption by travelers, especially when accompanied by spicy foods and alcohol. At best, travellers could hope for indigestion, but a fatal dysentery was more likely. ${ }^{65}$ The doctor Hipólito Unanue, one of the founders of the Peruvian society, agreed that these windy roots, eaten by Lima's poor, tended to turn sour in the stomach, and so were best avoided. ${ }^{66}$ Far from promoting potato consumption, Peru's community of patriotic savants discouraged its use.

In reality, potatoes were a significant commercial crop in eighteenth-century Peru. From the earliest days of the colony potatoes had formed part of the tribute demanded of Amerindians, because Spaniards recognized their potential as a commodity. They remained an important item of commerce within the viceroyalty and between neighboring colonies. Grown by indigenous and

62. Apuntes de los gastos del Monasterio de Santa Tereza de Jesús ... desde 19 de abril de 1794, año 2; and Sobre seglares de Santa Catalina, y alimentos de religiosas, refectorio, etc., March 1, 1796; both in Archivo Arzobispal de Arequipa, Arequipa, Santa Teresa, legajo 2, and Santa Catalina, legajo 8, respectively; Antonio Leon Pinelo, Question moral si el chocolate quebranta el ayuno eclesiástico (Madrid, 1638), 57, 63; Jeffrey Pilcher, iQue vivan los tamales! Food and the Making of Mexican Identity (Albuquerque: University of New Mexico Press, 1998); and Rebecca Earle, The Body of the Conquistador: Food, Race and the Colonial Experience in Spanish America, 1492-1700 (Cambridge: Cambridge University Press, 2012).

63. "Idea general del Perú"; "La Province of Caxatambo"; and "Descripción de la Provincia de Chachapoyas"; all in MP 5 (1792), 6, 190, 194, 225; Alonso Carrió de la Vandera, El lazarillo de ciegos caminantes desde Buenos Aires, hasta Lima [1773], Biblioteca Virtual Miguel de Cervantes, 301, 335; Joseph Ignacio Lequanda, "Descripción de Caxamarca," MP 10 (1794), 202; and Francisco López, "Descripción de Porco," MP 11 (1794), 19, 29-30, 37-38, 63, 68-72, 77, 87-89, 92.

64. José Manuel Dávalos, De morbis nonmullis Limae, grassantibus ipsorumque therapeia (Montpellier, 1787), 11-12. Dávalos was obliged to matriculate in France because Peruvian universities would not accept those who like Davalos were classified as mulattoes.

65. Panacio Montano, "Medicina práctica," MP 1 (1791), 45-47

66. Hipólito Unanue, Observaciones sobre el clima del Limay sus influencias en los seres organizados (Lima, 1806), 153. On wind, see also Juan del Valle y Caviedes, "Defensas que hace un ventoso al pedo," Obra completa, Daniel Reedy, ed. (Caracas: Biblioteca Ayacucho, 1984), 277. 
non-indigenous farmers alike, potatoes were traded up and down the Andes and along the Pacific coast, providing a handsome profit for those able to mount a large-scale trade, as the Mercurio itself documented. Potato prices in the Lima market in fact increased during the years of the paper's publication. ${ }^{67}$ Within the pages of the Mercurio, then, "potato" was at once a profitable commodity, a despised food, and an example of Hispanic enlightenment.

\section{CONCLUSION}

These stories reveal much about the role of food in the eighteenth-century enlightened imagination. The historian Javier Usoz has noted that during the Enlightenment "writing about economics . . . was the equivalent of writing about politics and governance." 68 The same might be said regarding writings about food. The close associations between strong populations, nourishing foods, and enlightened governance meant that elite discussions of diets were rarely concerned solely with practical matters of supply, important though these were. This is particularly clear in the discussions of Spain's role in bringing potatoes to Europe. For enlightened patriots in Spain and the Indies, the dissemination of this valuable root provided concrete evidence that Spain's colonization of the Americas had advanced the well-being of all mankind. From this perspective, the appeal of potatoes lay in their ability to symbolize benevolence, improvement, and public happiness. Praising potatoes was a form of participation in the republic of letters.

As Antonello Gerbi demonstrated half a century ago, Spain's place within this bright circle of enlightened nations was severely questioned by other European philosophers. In the Encyclopédie Denis Diderot and Jean le Rond D'Alembert described Spain as a torpid backwater whose inhabitants preferred to loll about drinking chocolate, rather than engage in philosophical inquiry or further the cause of useful knowledge. 69 "With few exceptions, the image that

67. López, "Descripción de Porco," 101-102; MP 11 (1794), 106; Manuel Espinavete López, "Descripción de la Provincia de Abancay," MP 12 (1795), 131, 137, 145-146, 156-157; Spalding, Huarochirí, 134, 163, 196-197; Marcel Haitin, "Prices, the Lima Market, and the Cultural Crisis of the Late Eighteenth Century in Peru," Jabrbuch für Geschichte von Staat, Wirtschaft und Gesellschaft Latein-amerikas 22 (1985).

68. Usoz, "Political Economy and the Creation of the Public Sphere during the Spanish Enlightenment," 105.

69. Louis, chevalier de Jaucourt, "Spain," Malcolm Eden, trans. (from original "Espagne"), Encyclopédie ou dictionnaire raisonné des sciences, des arts et des métiers, vol. 5 (Paris, 1755); Jean-François de Saint-Lambert, "Luxury," Claude Blanchi, trans. (from "Luxe"), Encyclopédie ou dictionnaire raisonné, vol. 9 (Paris, 1765); and Louis, chevalier de Jaucourt, "Inquisition," Robin Vose, trans. (from "Inquisition"), Encyclopédie ou dictionnaire raisonné, vol. 8 (Paris, 1765); all from The Encyclopedia of Diderot es d'Alembert Collaborative Translation Project (https://quod.lib.umich.edu/ $\mathrm{d} / \mathrm{did} /$ ). The "Vanilla" entry notes that "for their part, the Spaniards, satisfied with the riches they have taken from [the natives], and more accustomed to a happy ignorance and lazy life, have scorned the lure of natural history and those who have succumbed to it." Louis, chevalier de Jaucourt, "Vanilla," Robert Ketchum, trans. (from "Vanille"), Encyclopédie on dictionnaire raisonné, vol. 16 (Paris, 1765), also from The Encyclopedia of Diderot es d'Alembert 
contemporaries offered is of a country resistant to enlightenment, rooted in superstition and ignorance, subject to the Inquisition, and ruled by the clergy," notes one study of Spain's image in eighteenth-century France. ${ }^{70}$ Nor were Spain's imperial ventures in the Americas viewed any more positively. Far from following philosophical and scientific developments, creoles spent their days sunk in "barbarous luxury, pleasures of a shameful kind, a stupid superstition, and romantic intrigues," in the opinion of writers such as the Abbé Raynal. ${ }^{71}$

These barbs stung, in part because Hispanic ilustrados knew them to be unjust. A growing scholarship now demonstrates that the Enlightenment sank deep roots into Spanish political culture. Projects as diverse as the reform of cooking facilities in Madrid poorhouses, the teaching of the new theories of political economy, and the promotion of improved agricultural practices were enthusiastically supported by private individuals, organizations, and the state as positive contributions to science and the public good. ${ }^{72}$ More than 50 scientific expeditions were dispatched around the globe by the Bourbon state, charged with collecting useful knowledge to enrich Spanish industry and promote enlightenment. Wealthy ladies not only hosted tertulias to discuss the latest developments in the arts and sciences, but themselves engaged in experiments and investigations into all manner of topics. The culture of improvement embraced artistic taste, military engineering, public health, popular morals, commercial monopolies, and much more. ${ }^{73}$

Collaborative Translation Project. For classic analyses of negative French and British attitudes toward both Spain and its colonies, see Gerbi, The Dispute of the New World; Anthony Pagden, Spanish Imperialism and the Political Imagination (New Haven: Yale University Press, 1990); David Brading, The First America, the Spanish Monarchy, Creole Patriots, and the Liberal State, 1492-1867 (Cambridge: Cambridge University Press, 1991); Jorge Cañizares-Esguerra, How to Write the History of the New World: Histories, Epistomologies, and Identities in the Eighteenth-Century Atlantic World (Stanford: Stanford University Press, 2001); and Mariselle Meléndez and Karen Stolley, "Introduction: Enlightenments in Ibero-America," Colonial Latin American Review 24:1 (2015).

70. María Victoria López-Cordón, "Limmagine della Spagna nella Francia del XVIII secolo: storia, società e carattere," Dimensioni e Problemi della Ricerca Storica 2 (1995): 111-137.

71. Guillaume-Thomas Raynal, A Philosophical and Political History of the Settlements and Trade of the Europeans in the East and West Indies, 10 vols. (London, 1798), 7:189. Or see William Robertson, The History of America, in The Works of William Robertson, 8 vols. (Oxford, 1825), 7:340, 342; Roy Porter, The Enlightenment, Macmillan (Basingstoke, UK: Palgrave Macmillan, 1990), 52; and Jonathan Israel, Radical Enlightenment: Philosophy and the Making of Modernity, 1650-1750 (Oxford: Oxford University Press, 2001), 3, 11.

72. For economical kitchens, see Carmen Abad-Zardoya, "Arquitectos en los fogones: del theatrum machinarum a los proyectos ilustrados para una cocina económica," Artigrama 26 (2011). For political economy, see Miguel Gerónimo Suárez, Memorias instructivas, y curiosas sobre agricultura, comercio, industria, economia, chymica, botánica, historia natural e (Madrid, 1778), 3:219ff. For agronomy, see Lluch and Argemí i d'Abadal, Agronomía y fisiocracia en España.

73. See, for instance, Sellés, Peset, and Lafuente, eds. Carlos III y la ciencia de la ilustración; Puerto Sarmiento, La llusión quebrada; Mónica Bolufer Peruga, Mujeres e ilustración: la construcción de la feminidad en la Ilustración española (Valencia: Diputació de València, 1998); Lafuente, "Enlightenment in an Imperial Context”; Cañizares-Esguerra, How to Write the History of the New World; Theresa Ann Smith, The Emerging Female Citizen: Gender and Enlightenment in Spain (Berkeley: University of California Press, 2006); Jorge Cañizares-Esguerra, Nature, Empire, and Nation: Explorations of the History of Science in the Iberian World (Stanford: Stanford University Press, 2006); Martínez Ruiz and De Pazzis Pi Corrales, eds., Ilustración, ciencia y técnica en el siglo XVIII español; Paquette, Enlightenment, Governance, and Reform in Spain and its Empire; Catherine Jaffe, Elizabeth Franklin Lewis, eds., Eve's Enlightenment: 
Spain's American colonies did not stand aloof from these concerns. Botanical gardens, astronomical observatories, schools of mining, reforms of primary education, campaigns for street lighting, and attempts to ban cockfighting and public drunkenness appeared across the hemisphere. Gentlemen scholars drafted reformist treatises infused with a belief in the power of human reason, while Catholic officials sought to reform religious practice to eliminate folk customs and baroque extravagances. Colonial officials and local philosophers engaged in the delicate balancing act of implementing such enlightened schemes while preserving or indeed reinforcing existing social hierarchies. ${ }^{74}$ The potato vogue in the eighteenth-century Hispanic world forms part of this broader enlightened program. Discussion of the potato and its contribution to human happiness resonated across the Atlantic. Spanish newspapers published articles on the tuber penned by Peruvian naturalists, and Peruvian and Guatemalan newspapers reprinted reports on investigations undertaken in Spain. Information did not flow unidirectionally.

In a recent essay on the global Enlightenment, the historian Sebastian Conrad suggested that scholars should focus less on the origin of ideas and practices, and more on their interconnections. Far from viewing the Enlightenment as a European phenomenon that radiated outward from Paris and London, scholars increasingly frame it as set of global encounters that were articulated locally. ${ }^{75}$ These local articulations were not mere echoes of events in Europe but rather possessed their own dynamics and internal logics. Nor can we separate the Enlightenment's European manifestations from these encounters in other parts of the world. Historians of science have demonstrated that during the

Women's Experience in Spain and Spanish America, 1726-1839 (Baton Rouge: Louisiana State University Press, 2009); Daniela Bleichmar, Paula De Vos, Kristin Huffine, and Kevin Sheehan, eds., Science in the Spanish and Portuguese Empires, 1500-1800 (Stanford: Stanford University Press, 2009); Andrea Smidt, "Luces por la Fe: The Cause of Catholic Enlightenment in 18th-Century Spain," A Companion to the Catholic Enlightenment in Europe, Ulrich Lehner and Michael O'Neill Printy, eds. (Leiden: Brill, 2010); Helen Cowie, Conquering Nature in Spain and its Empire, 1750-1850 (Manchester: Manchester University Press, 2011); Bleichmar, Visible Empire; and Astigarraga, ed., The Spanish Enlightenment Revisited.

74. See, for instance, Viqueira Albán, Propriety and Permissiveness; Jeremy Adelman, Republic of Capital: Buenos Aires and the Legal Transformation of the Atlantic World (Stanford: Stanford University Press, 1999); Lafuente, "Enlightenment in an Imperial Context"; Pamela Voekel, Alone before God: The Religious Origins of Modernity in Mexico (Durham: Duke University Press, 2002); Renan Silva, La ilustración en el Virreinato de Nueva Granada (Medellín: La Carreta, 2005); Castro-Gómez, La hybris del punto cero; Mauricio Nieto Olarte, Orden natural y orden social: ciencia y politica en el Semanario del Nuevo Reino de Granada (Madrid: Consejo Superior de Investigaciones Científicas, 2007); Neil Safier, Measuring the World: Enlightenment Science and South America (Chicago: University of Chicago Press, 2008); Bleichmar, De Vos, Huffine, and Sheehan, eds., Science in the Spanish and Portuguese Empires; Meléndez, Deviant and Useful Citizens; Soule, The Bishop's Utopia; and Paquette, ed., Enlightened Reform in Southern Europe and its Atlantic Colonies.

75. Sebastian Conrad, "The Enlightenment in Global History: A Historiographical Critique," American Historical Review 117:4 (2012); and Sebastian Conrad, What is Global History? (Princeton: Princeton University Press, 2016), 76 (quote). Or see Bianca Premo, The Enlightenment on Trial: Ordinary Litigants and Colonialism in the Spanish Empire (Oxford: Oxford University Press, 2017). 
eighteenth century extra-European dialogue played a central role in the construction of enlightened European knowledge itself. "Important parts of what has been passed off as European, or Western, science were actually made elsewhere," the historian Kapil Raj has observed. ${ }^{76}$ For example, the botanical knowledge displayed in Madrid's royal gardens of necessity relied on complex interactions that took place far from Spain between indigenous people, local elites, mobile scientists, and enlightened officials. ${ }^{77}$ From this perspective the Enlightenment is best seen as a multiplicity of complex interactions between Europeans and diverse communities around the world.

The eighteenth-century circulation of potato talk across the Hispanic world forms part of this larger history of the circulation of enlightened knowledge, which in turn points to the traveling nature of the Enlightenment itself. Potatoes resonated differently in Lima, Madrid, and Guatemala, but in all three locations discussion of their merits formed part of a body of ideas whose central themes were the relationships between nutritious food, good governance, and happiness. Living the Enlightenment, the geographer Charles Withers reminds us, was always "a form of local cultural production and consumption," in which different discourses and practices interacted. Thinking about place, he suggests, helps make sense of the multiple, contested experiences of the Enlightenment. $^{78}$ Examining these potato histories provides one way to concretize our understanding of the simultaneously mobile and localized nature of enlightened projects and imaginaries, as well as the important role that food, and eating, played in them.

University of Warwick, Coventry, England

REBECCA EARLE Rebecca.Earle@warwick.ac.uk

76. Kapil Raj, Relocating Modern Science: Circulation and the Construction of Knowledge in South Asia and Europe, 1650-1900 (Houndmills, UK: Palgrave Macmillan, 2007), 11. See McClellan and Regourd, "The Colonial Machine"; Kapil Raj, "Colonial Encounters and the Forging of New Knowledges and National Identities: Great Britain and India, 1760-1850,” Osiris 15 (2000); Dipesh Chakrabarty, Provincializing Europe: Postcolonial Thought and Historical Difference (Princeton: Princeton University Press, 2000); Cañizares-Esguerra, Nature, Empire and Nation; Safier, Measuring the World; Lissa Roberts, "Situating Science in Global History: Local Exchanges and Networks of Circulation," Itinerario 33:1 (2009); and McClellan, Colonialism and Science.

77. Lafuente, "Enlightenment in an Imperial Context," 162; Safier, Measuring the World; Bleichmar, Visible Empire; Soule, The Bishop's Utopia.

78. Charles Withers, Placing the Enlightenment: Thinking Geographically about the Age of Reason (Chicago: University of Chicago Press, 2007), 14. 